make their own decisions on programs. This has resulted in an inappropriate specialty structure-in particular, an excessive quantity of graduates in economics and law.

As for graduates, they have to search for jobs on their own. The competitiveness of graduates in the labor market depends not only on their specialty, the prestige of the institution, excellent grades, but also on their professional experience. This is one of the main reasons why full-time students take jobs and prefer the more practical disciplines. Given the impoverishment of a large part of the population, another reason students engage in part-time work is to earn some money. This is also true of faculty. Part-time work takes a lot of time, which negatively affects the quality of education and teaching. For example, according to sociological surveys, most working students tend to pay less attention to their studies and lose interest, especially if their jobs do not correspond to their future specialties or they believe that after graduating they will not be able to find jobs in their fields.

\section{Higher Education and Society}

Considering the role and the place of higher education in society, it is important to address the issue of access to education and relationships between higher education and society. During much of the Soviet period, government promoted a policy of full access to higher education for all social strata. However, at present there is an increasing trend of declining access to higher education. Most students (up to 60 percent in some estimates) come from high- and middle-income groups, which comprise approximately onethird of the population. There a several causes of declining higher education access: a significant gap between secondary and higher education-some school graduates cannot gain admission to higher educational institutions without additional paid preparation; the high cost of living, which means that provincial youth are unable to leave home or spend their time on study rather than on earning money. The latter issue also leads to the so-called regionalization of education. Thus, currently, Russian higher education has become an obstacle to social mobility and a powerful tool for stratification.

\section{Reforming Higher Education}

Analysis of current trends in Russian higher education shows that the system faces many challenges: filling up gaps in the law, acquiring management and marketing skills, improving the quality of teaching, finding a balance between federal educational requirements and regional needs, and many others. The first stage of educational reform began in 1986, and the second was to follow in 1997. Two reform options have been debated, but neither has been accepted as yet. Although the proposed plans were imperfect, the discussion revealed that Russian society is not yet ready to undertake radical educational reform.

\section{Employment and Working Conditions of Academic Staff in the European Union}

\section{Jürgen Enders}

Jürgen Enders is on the staff of the Center for Research on Higher Education and Work, Gesamthochschule Kassel, Henschelstr. 4, D-3500 Kassel, Germany. E-mail: <enders@hochschulforschung.uni-kassel.de>.

For 20 years, the academic profession has come under increasing scrutiny. A growing body of literature has emerged on the academic profession in comparative perspective, focusing on closely interrelated problems.

First, the academic profession seems to have suffered a more rapid status loss than in the past. In many countries, the professoriate is seen as having lost its high rank in reputation among various professions, relative losses of income are reported, and junior positions are becoming more risky and less well paid. The notion that academics-the members of an expanding profession with growing importance for society-might consider themselves losers has arisen over the last two decades more strikingly than during previous periods.

Second, the resources at institutions of higher education have become more constrained than in the past. In many industrial countries, the allocation for teaching staff has increased, while basic funding for research has declined. Some of the developments might be called "efficiency gains," but overall the feeling of the impoverishment of higher education is widespread.

Third, the academic profession might lose a considerable portion of its academic guild powers. We note a rise in managerial power within higher education as well as increasing regulatory activities as regards the performance of academics.

Fourth, the academic profession is increasingly publicly blamed for not providing the necessary services to society. The critique ranges from a claim that the academic profession is not adequately ensuring quality standards to the widespread accusation that graduates have not acquired the knowledge and skills required and that research is not sufficiently addressing the most pressing problems of our times.

The sense of "crisis" in the academic profession, the changing role of government in higher education, and hopes for the managerial "miracle" have coincided to create a perception of changing environments and a loss of traditional patterns within the academic profession. The current context involves a decline in status-in terms of public reputation and remuneration; deprofessionalization-in terms of loss of control over tasks and working conditions; a loss of trust in self-steering as opposed to accountability 
and evaluation; a decline in the specific privileges of the professoriate; an increase in the flexible and casual nature of the academic work force; and a decrease in the attractiveness of the academic career.

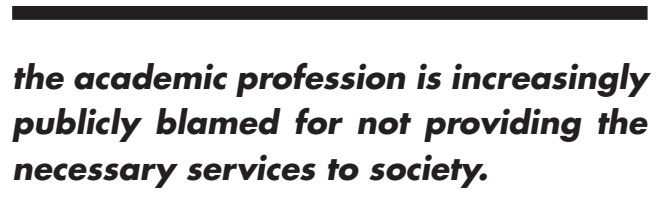

In summer 1998, the Center for Research on Higher Education and Work in Kassel, Germany, initiated a project called "The Employment and Working Conditions of Academic Staff in Higher Education: A Comparative Study in the European Community." The project's aim is to deepen our understanding of recent developments in this area, thus contributing to an international discussion in which widely held claims about the academic profession are not just taken for granted, but also tested. Experts from 15 countriesAustria, Belgium, Denmark, Finland, France, Germany, Greece, Ireland, Italy, the Netherlands, Norway, Portugal, Spain, Sweden and the United Kingdom-have been invited to write country reports highlighting developments over the last two decades and the state-of-the-art of the academic profession in the different national contexts. Publication of the first results in comparative perspective is expected in winter 1999 .

The study has three main objectives: first, to analyze major traditional features of the academic profession and its occupational ranking and career structure and to gather up-to-date information about the employment and working conditions of academic staff in the European countries involved. The data and analysis cover issues related to staff structure, academic appointment and employment arrangements, and academic careers. Second, the study analyzes the distribution of responsibility and power among the relevant actors and changes in the rules and regulations covering staffing in higher education. Third, the study is analyzing changes in the employment and working conditions of academic staff over the last several years and current debates on these issues: to what extent are various aspects of employment and working conditions an explicit or implicit target of reorganization? What are the underlying assumptions and aims? What are the perceived impacts of these developments on the positioning of the academic profession?

The preliminary results were discussed by the country experts and higher education policymakers in an international project conference held in April 1999 in Kassel. The study appears to have been a mostly timely one: many European countries are in the midst of reorganizing the actors and procedures in higher education and the rules and regulations covering employment relationships among academic staff. The study is, therefore, examining a moving target of growing concern for the future of higher education and its most important asset-the academic staff.

\section{The Question of Degrees in Canadian Higher Education}

\section{Paul Goyan and Glen A. Jones}

Paul Goyan is a doctoral student in the Higher Education Group of the Ontario Institute for Studies in Education of the University of Toronto (OISE/UT). Glen A. Jones is Associate Professor of Higher Education, OISE/UT, 252 Bloor Street West, Toronto, Ontario, Canada, M5S 1 V6.

$\mathrm{T}$ he Canadian higher education policy environment is highly decentralized, and yet scholars have noted that during the period from 1945 until the late 1960s, a common institutional form slowly evolved. Pushed by student demand and pulled by government funding policies that differed by province, Canadian universities gradually became defined as public, secular, comprehensive, high-access, degree-granting institutions. The Canadian universities' public monopoly over degree granting has been recently challenged by initiatives in the provinces of British Columbia and Alberta that extend limited degree-granting authority to institutions in the nonuniversity sector in order to improve accessibility and to increase the production of technical graduates.

Until recently, British Columbia had three universities: the University of British Columbia, established in 1915; and the University of Victoria and Simon Fraser University, established in the 1960s. During the 1960s, the province established a system of community colleges that provided vocational education as well as first- and second-year university transfer courses. The BC Council on Admissions and Transfers facilitates articulation between the community colleges and universities. The province also has an Open University and an Open College delivering vocational and degree-level programs as part of the $\mathrm{BC}$ Open Learning Agency. In the 1980s, BC became the first province to charter a private, sectarian university-Trinity Western—through a private member's bill in the legislature.

Although BC has a large community-college sector, youth participation in university education in the province has been among the lowest in Canada. As a result, the provincial government created a number of new institutions in the 1990s and made some changes to the mission of existing community colleges. The University of Northern British Columbia was established using the research 